\title{
The Role of SIDBI in developing the MSMEs in India
}

\author{
K. Sankara Rao ${ }^{1}$, Abdul Rahman Noorinasab. ${ }^{2}$ \\ ${ }^{1,2}$ Department of Commerce\& Management Studies, Andhra University
}

\begin{abstract}
The Micro, Small and Medium Enterprise (MSME) sector plays a vital role in the growth of our country in creating employment, exports, gross industrial value of output, gross value added, investment in fixed assets, contribution to GDP, and giving boost to manufacture, service and infrastructure sectors. The opportunities in MSME sectors are enormous due to the factors like Less Capital Intensive, Extensive Promotion \& Support by Government, Reservation for Exclusive Manufacture, Funding by way of Finance \& Subsidies, Reservation for Exclusive Purchase by Government, Export Promotion, great demand in the domestic market, export potential and so on.

The number of MSMEs functioning in the country as per Quick Results of $4^{\text {th }}$ All India Census (2006-07), in the registered and unregistered categories are 1.55 Million (5.94\%) and 24.55 Million (94.06\%) respectively. The Micro, Small and Medium Enterprises Development (MSMED) Act, 2006 has given choice to entrepreneur that the filing of Memorandum (Registration) by Entrepreneur intending to establish a Micro, Small or Medium Enterprise is discretionary and not mandatory. In this study, besides making a brief review of the overall performance of the MSME sector, the role played by the Small Industries Development Bank of India (SIDBI) in empowering MSMEs and acting as the nodal agency for SME schemes of Government of India, have been described.
\end{abstract}

Key words: MSMED Act, Export promotion, Memorandum, SIDBI, FIVE YEAR PLAN, Census

\section{Introduction:}

The global economy is expected to show a gradual strengthening of activity in 2013 from the relatively disappointing pace of early 2012 and record a higher growth of 3.6\% as against 3.3\% in 2012. The growth will be led by the USA, China, Japan and Middle East and North Africa (MENA) countries. Similarly, the Indian economy is poised on a recovery path with expected higher growth momentum in financial Year 2012-13.

A number of positive factors are working to create a growth enabling eco-system for the MSME sector. First, favourable credit policy measures, such as 20 percent annual credit growth to MSMEs, 60 percent of the MSME credit to be embarked for micro enterprises and 10 per cent annual growth in the number of micro enterprise accounts. More importantly, its continuous monitoring by Government of India and Reserve Bank of India will enhance credit access to the sector. Second, major constraints of MSME sector are now being addressed by SIDBI's new business model which is oriented towards filling the financial gaps and developmental gaps in the MSME eco-system. In its new business model, SIDBI would be providing venture / risk capital, energy efficiency investment loans, bills discounting / factoring which are generally not being provided adequately to MSMEs by banks. Credit flow to MSME sector will be further augmented by SIDBI's initiatives in setting up of Credit Advisory Centres with industry associations in clusters and providing loan facilitation / syndication services.

Third, a major constraint of information gap in MSME sector is now being addressed by SIDBI's newly launched website "www.smallB.in" which not only handholds a new entrepreneurs to set up units, but also provides all necessary information to existing entrepreneurs to grow in future. Fourth, certain policy measures like early resolution of Non Performing Assets( NPAs) and sickness in MSME sector, opening up of specialized MSME branch / cell in MSME clusters, easier access to FOREX loans by MSMEs, launching of innovative bank branches exclusively for financing innovative MSMEs, mandatory $20 \%$ procurement from MSE sector by Public Sector Undertakings / Government departments, opening up of defence sector to MSMEs, etc. will go a long way to help MSMEs achieve a higher and sustainable growth in coming years.

\section{Methodology:}

The Data required for the study has been collected from secondary sources. The Data Collection includes (i) Annual Reports of SIDBI; (ii) SIDBI's Reports on MSME Sector; (iii) Ministry of MSME's releases; (iv) RBI Annual Reports, (v) Various Websites relevant to topics.

\section{Budgets 2012-13, 2013-14 high lights for MSME:}

3.1)With the objective of promoting market access of MSEs, the Government has approved a policy which requires ministries and Central Public Sector Enterprises to make a minimum of $20 \%$ of their annual 
purchases from MSEs. Of this, 4\% will be earmarked for procurement from MSEs owned by Schedule Caste/Schedule Tribe entrepreneurs.

3.2) The turnover limit for compulsory tax audit of accounts as well as for presumptive taxation would be raised from ` 60 lakh to ` 1 crore for Small \& Medium Enterprises. In order to augment funds for SMEs, capital gains tax on sale of a residential property would be exempt, if the sale consideration is used for subscription in the equity of a manufacturing SME company for purchase of new plant and machinery.

3.3)Small and medium enterprises, including start-up companies, will be permitted to list on the SME exchange without being required to make an initial public offer (IPO)

3.4) If an MSME grows into a larger enterprise, no tax for three years after its growth

3.5) Small and medium companies to be allowed to listed on MSME exchange without making a public offer

3.6) Re-financing capacity of SIDBI increased to Rs. 10,000 crore from Rs. 5,000 crore for Ministry of Small and Medium Enterprises

3.7) National Skill Development Corporation to train 5 crore people in current plan period

3.8) To modernize power loom sector, minister announced technology upgrade scheme for textile sector to get INR 2400 crore

3.9) Youngsters who are skill trained to be given boost in employment and productivity; 10 lakh youth can be motivated in one year

3.10) To allocate Rs 1000 crore to extend skills of youth

3.11)With help of Ministry of S\&T, Centre has identified amazing innovations; will allocate Rs. $200 \mathrm{cr}$ to scale them and make them available to people

\section{RBI's first quarter (2013) monetary policy:}

4.1) Repo Rate is unchangedat7.25 The Reverse Repo Rate under the LAF, determined with a spread of 100 basis points below the repo rate, accordingly adjusted to 6.25 per cent.

4.2) Marginal standing facility (MSF) and bank rate stood at $10.25 \%$

4.3) Current reserve ratio too unchanged at $4 \%$ and cuts GDP forecast for FY14 to $5.5 \%$ from $5.7 \%$ earlier.

\section{Highlights of Annual Supplement (2013-14) to the Foreign Trade Policy 2009-14 by Ananda}

\section{Sharma}

5.1) Measures to revive investors ${ }^{\text {ec }}$ interest in SEZs: A package of measures has been formulated to revive investors" interest in SEZs and to boost exports. The salient features of the package are:- In view of the acute difficulties in aggregating large tracts of uncultivable land for setting up SEZs, while ensuring vacancy and contiguity, we have decided to reduce the Minimum Land Area Requirement by half. For Multiproduct SEZ from 1000 hectares to 500 hectares and for Sector-specific SEZ from existing 100 hectares to 50 hectares.

5.2) Zero Duty Export Promotion Capital Goods (EPCG) Scheme: Foreign Trade Policy has two variants under this scheme, namely, Zero Duty EPCG for few sectors and 3\% Duty EPCG for all sectors. During the last announcement on 5th June, 2012, a new Post Export EPCG Scheme was also announced which was notified on 18 February, 2013 by the CBEC.

Based on the request of all stakeholders, Government has decided to harmonize Zero Duty EPCG and 3\% EPCG Scheme into one scheme which will be a Zero Duty EPCG Scheme covering all sectors.

5.3) Reduced EO for Domestic Sourcing of Capital Goods: The quantum of specific Export Obligation (EO) in the case of domestic sourcing of capital goods under EPCG authorizations has been reduced by $10 \%$. This would promote domestic manufacturing of capital goods.

5.4) Widening of Interest Subvention Scheme: At present, $2 \%$ interest subvention scheme is available to certain specific sectors like Handicrafts, Handlooms, Carpets, Readymade Garments, Processed Agricultural Products, Sports Goods and Toys. The scheme had been further widened to include 134 sub-sectors of engineering sector. Government had also announced that the benefit of this scheme of $2 \%$ interest subvention could be available up to 31.03 .2014 .

\section{Credit Flow to Micro and Small Enterprises Sector (MSE) by Scheduled Commercial Banks (SCBs)}

6.1) Advances to micro and small enterprises (MSE) sector shall be reckoned in computing achievement under the overall Priority Sector target of 40 percent (32 percent for Foreign Banks operating in India with less than 20 branches) of Adjusted Net Bank Credit (ANBC) or credit equivalent amount of Off-Balance Sheet Exposure, whichever is higher.

6.2) 40 per cent of the total advances to MSE sector should go to micro (manufacturing)enterprises having investment in plant and machinery up to Rs. 10 lakh and micro (service) enterprises having investment in equipment up to Rs. 4 lakh; 
6.3) 20 per cent of the total advances to MSE sector should go to micro (manufacturing) enterprises with investment in plant and machinery above Rs. 10 lakh and up to Rs. 25 lakh, and micro (service) enterprises with investment in equipment above Rs. 4 lakh and up to Rs. 10 lakh. Thus, 60 per cent of MSE advances should go to the micro enterprises.

6.4) While banks are advised to achieve the $60 \%$ target as above, in terms of the recommendations of the Prime Minister's Task Force, the allocation of $60 \%$ of the MSE advances to the micro enterprises is to be achieved in stages viz. $50 \%$ in the year $2010-11,55 \%$ in the year $2011-12$ and $60 \%$ in the year $2012-13$.

\section{Role of Small Industries Development Bank of India:}

Small Industries Development Bank of India (SIDBI), set up on April 2, 1990 under an Act of Indian Parliament, is the Principal Financial Institution for the Promotion, Financing and Development of the Micro, Small and Medium Enterprise (MSME) sector and for Co- ordination of the functions of the institutions engaged in similar activities.

Financial support is provided by way of refinance to eligible Primary Lending Institutions (PLIs) such as banks, State Financial Corporation's (SFCs), State Industrial Development Corporations (SIDCs), State Small Industries Development Corporations (SSIDCs) etc. for onward lending to MSMEs, financial assistance in the form of loans, grants, equity and quasi- equity to Non Government Organisations / Micro Finance Institutions (MFIs) for on-lending to micro enterprises and economically weaker sections of society, enabling them to take up income generating activities on a sustainable basis and direct assistance to MSMEs which is channelized through the Bank's network of 103 branch offices.

SIDBI plays a significant role in promotion, financing and development of MSMEs and coordinating the functions of institutions engaged in similar activities. Its sphere of activities include (i) Direct Finance Operations to MSMEs and Service Sectors besides Infrastructure; (ii) Indirect Finance by way of resource support to Banks, NBFCs, SFCs, and other Central Financing/Development Agencies, Development of Micro Credit Institutions; (iii) Promotion of Associate Institutions like Venture Capital, Rating Agency, Credit Guarantee Fund, Asset Reconstruction Company and so on; and (iv) Nodal Agency for Government of India MSME Schemes like Technology Up gradation Fund Scheme (TUFS), Credit Linked Capital Subsidy Scheme (CLCSS), Integrated Development of Leather Sector Scheme, Development of Infrastructure Development Projects and a few. SIDBI's focus is on development of manufacturing, service and infrastructure sectors through the growth of MSMEs and their promotion

\section{Strategic Business Initiatives and Overall Operations:}

The business strategy of SIDBI has been reoriented towards filling up the financial and non- financial gaps in the MSME eco-system. SIDBI would extend refinance to Banks and Non- Banking Financial Companies (NBFCs) and also extend capacity building support to smaller commercial banks, Regional Rural banks (RRBs), Urban Co-operative banks (UCBs) and District Cooperative Banks (DCBs). In addition, direct finance to MSMEs is being targeted at niche areas to address various financial gaps through specially designed products like risk capital, sustainable finance, factoring, invoice discounting, services sector financing, etc.

\section{a) Addressing financial gaps:}

The equity/risk capital assistance has supported the growth requirements of a number of MSMEs including leveraging of senior loans, funding intangible requirements like expenditure for Research \& Development, marketing / brand building, technical know-how, energy efficiency, quality control, working capital margin, etc. where bank loans are generally not available. SIDBI also provides such risk capital assistance selectively to start- ups and early stage ventures operating in innovative businesses/ technology space, including those being incubated at technology incubators.

During Financial Year 2011-12, Direct Risk Capital Scheme (DRCS) has been rechristened as Growth Capital \& Equity Assistance Scheme for MSMEs (GEMs), with some modifications and additional features so as to assist greater number of MSMEs. SIDBI has also put in place a scheme to provide risk capital assistance to MSMEs by way of line of credit / resource support through Channel Partners (CPs)/ NBFCs with an objective of enhancing the retail reach of risk capital

SIDBI has executed a Memorandum of Understanding (MoU) with Technology Information, Forecasting and Assessment Council (TIFAC) for implementing the Technology Innovation Programme (Srijan Scheme). A revolving innovation fund of ' 30 crore has been created by TIFAC under the scheme. The main objective of the scheme is to support MSMEs towards development, up-scaling, demonstration and commercialization of innovative technology based projects.

SIDBI has been operating focused lending schemes with Line of Credit (LoC) support from various multilateral/bilateral international agencies, such as, Japan International Cooperation Agency (JICA) Phase IJPY 30 billion \& Phase-II - JPY 30 billion, Kreditanstalt fur Wiederaufbau (KfW), Germany - EUR 50 million; 
and Agence Francaise de Developpement (AFD), France - EUR 50 million. The main objective of these focused lending schemes is to enhance energy efficiency, reduce $\mathrm{CO}$ emissions and improve the profitability of the Indian MSMEs in the long run.

SIDBI has contracted EURO 38.5 million LoC from KfW, Germany for promoting investment in cleaner production options in the MSME sector. The main objective is to achieve reduction of emission and pollution through cleaner production investments. Investment, such as, Common Effluent Treatment Plants (CETPs), Waste Treatment, Storage

\& Disposal Facilities, Waste recycling, etc., benefitting large number of MSMEs in the industrial clusters are also eligible under the assistance.

The awareness about the environmental aspects among the MSMEs has increased in the areas of energy efficiency, waste recycling, waste treatment and disposal, ISO certifications, energy audit, Bureau of Energy Efficiency (BEE) star rating of their products, green ratings etc., for sustainability of their manufacturing facilities. SIDBI introduced 'Green Loan Scheme' to assist MSMEs to meet their capital expenditure, nonoperational and intangible expenditure for improving energy efficiency/adopting cleaner production measures, etc

\section{b) Addressing Non-financial Gaps:}

In addition to providing credit directly and indirectly, SIDBI has put in place a system for loan facilitation / syndication services to MSMEs to help them avail credit from banks/FIs. The system envisages creating a scalable eco-system for loan syndication involving MSMEs, accredited MSME Project Consultants / Technological Consultancy Organisations (TCOs), SIDBI staff, Rating Agencies - to bring in more credibility to the evaluation process for enabling MSMEs in securing bank credit.

In order to further enable MSMEs to access credit from banks, SIDBI has taken the initiative to set up Credit Advisory Centres (CACs) with industry associations in select MSME clusters, where the MSMEs are provided free consultancy / advisory services by SIDBI officials and retired bankers in getting credit from banks \& FIs. Already 41 such centres covering 150 clusters have been set up by SIDBI.

MSMEs are found to be lacking in information on how to start a business, Govt. schemes, sources of various finances, marketing, technology, etc. In order to address the information gap, SIDBI has launched a website named as ,www.smallB.in" which acts as virtual mentor and handholding tool for entrepreneurs to set up new units and grow the existing ones. Further, SIDBI, along with GIZ, Germany, has initiated financial literacy campaign among MSMEs in different clusters.

\section{Subsidiaries and Associate Organisations of SIDBI:}

Apart from addressing various financial and non-financial needs, SIDBI has also created an enabling institutional eco-system to address specific requirements of MSMEs through its subsidiaries / associate concerns. First, SIDBI Venture Capital Ltd. was set up in July, 1999 for providing venture capital assistance to knowledge based MSMEs. Presently SVCL is managing three venture capital funds, viz. the National Venture Fund for Software and Information Technology Industry, SME Growth Fund and India Opportunity Fund for providing venture capital assistance Similarly, to encourage banks / FIs to provide more credit to MSMEs, SIDBI along with Govt. of India set up Credit Guarantee Fund Trust for Micro and Small Enterprises in 2000 to provide credit guarantee coverage to collateral free / third-party guarantee free loans upto ` 1 crore extended by banks/FIs to micro and small enterprises. This acted as a game changer in as much as that more than 9.33 lakh MSE loan account with credit guarantee coverage were provided financial assistance by banks / FIs by end October, 2012.

Again, to support banks in quicker credit sanction to MSMEs, SIDBI, along with few Public Sector banks and Dun \& Bradstreet (D\&B), set up SME Rating Agency of India Ltd. (SMERA) in September 2005 an MSME dedicated third-party rating agency to provide comprehensive, transparent and reliable ratings and risk profiling. Cumulatively as on September 30, 2012, SMERA has assigned ratings to 17,725 MSME units, out of which micro enterprises constituted 65\%. India SME Technology Services Limited (ISTSL), was set up by SIDBI in November 2005, which provides a platform for MSMEs to tap opportunities at the global level for acquisition of modern technologies.

SIDBI has also set up, India SME Asset Reconstruction Company Ltd. (ISARC), country's first MSME focused ARC striving for speedier resolution of non-performing assets (NPA) by unlocking the idle NPAs for productive purposes which would facilitate greater and easier flow of credit from the banking sector to the MSMEs. It started operations in April 2009.

\section{SIDBI as Nodal Agency for Government Schemes:}

In addition to its direct and indirect operations, SIDBI also plays a pivotal role in implementation of various schemes for MSME sector undertaken by the Government of India (GoI). SIDBI continued to play an 
important role as a nodal agency in the implementation of GoI schemes, viz. Credit Linked Capital Subsidy Scheme (CLCSS) [Ministry of MSME], Technology Up gradation Fund Scheme for Textile Industry (TUFS) [Ministry of Textiles], Integrated Development of Leather Sector Scheme (IDLSS) [Ministry of Commerce \& Industry] and Scheme of Technology Up gradation / Setting up / Modernisation / Expansion of Food Processing Industries (FPTUFS) [Ministry of Food Processing Industries].

\section{International Collaborations:}

The Bank has signed an agreement with Kreditanstalt fur Wiederaufbau (KfW), Germany for loan support of EUR 85 million and Technical Assistance for improving access to microfinance products in India among the poor, particularly women. The loan component of the support is being used to provide loans to MFIs for on-lending. The Technical Assistance component is being used to provide training to assisted MFIs, creation of a web-based platform, development of a risk assessment module, select capacity building interventions in the area of transfer of industry benchmarks, best practices to assisted MFIs and for carrying out of loan portfolio audits / system audits of the Bank"s assisted MFIs, as a prudent risk management measure.

The Bank has entered into collaboration with Asian Development Bank (ADB) for loan support of USD 50 million which would provide SIDBI with long tenor funding to support the vital "Missing Middle" through specific financing programmes. The loan is accompanied by Technical Assistance of up to USD 3 million from Japan Fund for Poverty Reduction.

\section{Promotional \& Developmental initiatives:}

Being the apex financial institution for the MSME sector, SIDBI adopts a „Credit Plus" approach under which Promotional \& Developmental (P\&D) activities are initiated with the twin strategy of creation of enterprises and strengthening of existing enterprises. SIDBI has benefitted the MSME sector through P\&D activities which helped in setting up of over 1 lakh enterprises, generating employment of around 3 lakh and benefitting around 4 lakh persons.

An important P\&D initiative of the Bank is the Micro Enterprises Promotion Programme (MEPP) which aims at promoting viable micro enterprises in rural areas leading to rural employment generation. Cumulatively, upto March 31, 2012, MEPP has been implemented in 121 districts in 24 States, thereby promoting more than 38,000 rural enterprises. Similarly, Entrepreneurship Development Programme (EDP) aims at promotion of self-employed ventures capable of generating employment opportunities, especially targeting less privileged sections of the society like Women, Scheduled Castes / Scheduled Tribes, minorities and the rural poor. As on March 31,2012, cumulatively number of EDPs supported by the Bank for various target groups was 2894 , benefitting more than 72,850 participants.

Similarly, the total number of Skill-cum-Technology Up gradation Programmes (STUPs) and Small Industries Management Programmes (SIMAPs) supported by the Bank since inception, till March 2012, were 1,504 and 295, respectively benefiting about 39700 participants. STUP aims at enhancing technology profile of MSME units and SIMAP targets qualified unemployed as well as industry-sponsored candidates, with the overall objective of providing competent managers to the MSME sector. SIDBI also accords special attention to the development of North Eastern Region (NER) through a package of micro finance, rural industrialisation, entrepreneurship development, marketing support, etc.

The special initiatives being pursued in the NER encompass MEPP in 22 districts, 39 Cluster Development Programmes (CDP) and various vocational training programmes, marketing activities, seminars, etc. These programmes have so far promoted more than 2500 units in NER. To accelerate industrial development in the north eastern part of the country, your Bank has enlisted North Eastern Development Financial Institution (NEDFi) as an eligible primary lending institution for refinance of loans to micro and small enterprises and a refinance limit of ' 50 crore was sanctioned to it during FY 2011-12. Your Bank has also set up Counselling Centres Shillong (Meghalaya), Silchar (Assam), Aizawl (Mizoram), Gangtok (Sikkim) and Agartala (Tripura).

In 2012-13, the financial institution provided loans to Micro, Small and Medium Enterprises (MSMEs) directly (term loan under direct credit schemes, MSME receivable finance, bulk credit\&Venture capital finance) and indirectly (Refinance, Equity assistance, Micro Finance including P\&D assistance Resource support to institutions) had disbursed Rs 41160 crore. SIDBI had identified four niche areas - risk capital, receivable financing, financing services sector and sustainable financing - where MSMEs need support. In the current fiscal, SIDBI set a 10 per cent higher disbursement target. 
All figures are in Rs.Crores:

\section{Overall performances:}

\begin{tabular}{|c|c|c|c|c|c|}
\hline Year & Sanctions & Disbursement & $\begin{array}{c}\text { Outstanding } \\
\text { Portfolio size }\end{array}$ & Income & Profit \\
\hline $2004-05$ & 9091 & 6189 & 10,862 & 948 & 225 \\
\hline $2005-06$ & 11975 & 9100 & 13,891 & 964 & 270 \\
\hline $2006-07$ & 11102 & 10225 & 16031 & 1187 & 298 \\
\hline $2007-08$ & 16164 & 15087 & 20226 & 1638 & 198 \\
\hline $2008-09$ & 29188 & 28298 & 30,886 & 2082 & 299 \\
\hline $2009-10$ & 35521 & 31919 & 37,969 & 2540 & 421 \\
\hline $2010-11$ & 42,214 & 38796 & 46,054 & 3,433 & 514 \\
\hline $2011-12$ & $45688^{*}$ & 41160 & 53,785 & 4607 & 567 \\
\hline $2012-13$ & $51565^{*}$ & $47859^{*}$ & $57522^{*}$ & 5401 & 837 \\
\hline
\end{tabular}

* - Projected values

Sources: Annual reports of SIDBI.

Bank during the year were higher at `4,606.63 crore mainly due to growth in the overall portfolio. The total expenditure during the corresponding period was higher at '2,796.21 crore. The Profit before Tax for the year was `1,074.14 crore and the net profit after tax and Deferred Tax Adjustment for the year was `566.85 crore. The Bank declared a dividend of $25 \%$ on paid-up equity capital of ' 450 crore which worked out to $` 130.75$ crore, inclusive of dividend distribution tax, surcharge and cess payable thereon.

Fig: Comparison of Sanction to Disbursement

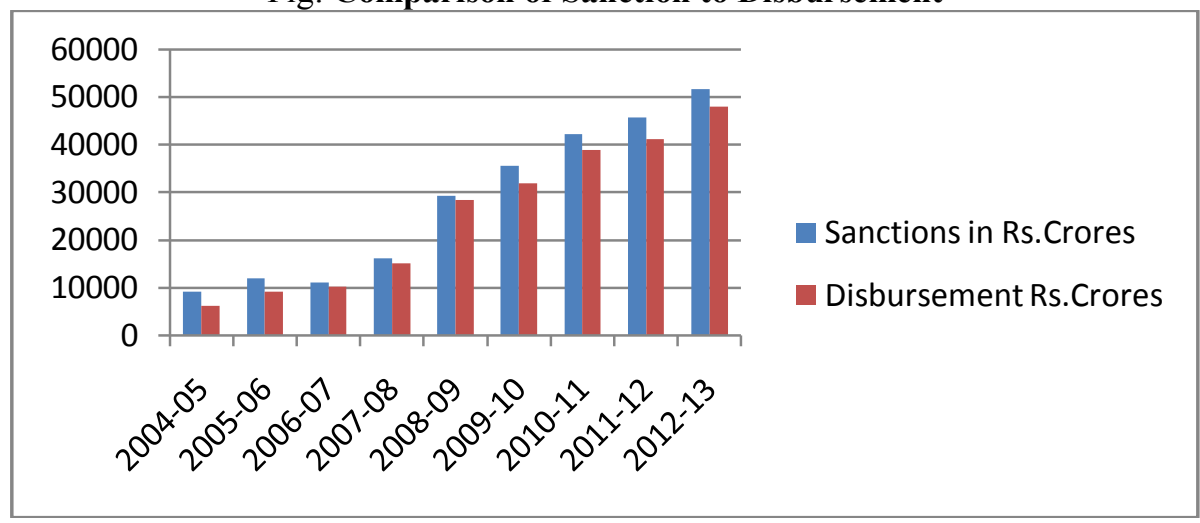

Note: SIDBI could maintain the growth in its credit disbursements to the MSME sector during FY 2011-12, despite economic sluggishness. The total MSME outstanding credit of the Bank increased by $16.7 \%$ to `53,785 crore as on March 31, 2012 .The cumulative disbursement by SIDBI to the MSME sector since inception stood at $2,44,286$ crore, benefitting more than 325 lakh persons.

Fig: Disbursement percentage YOY

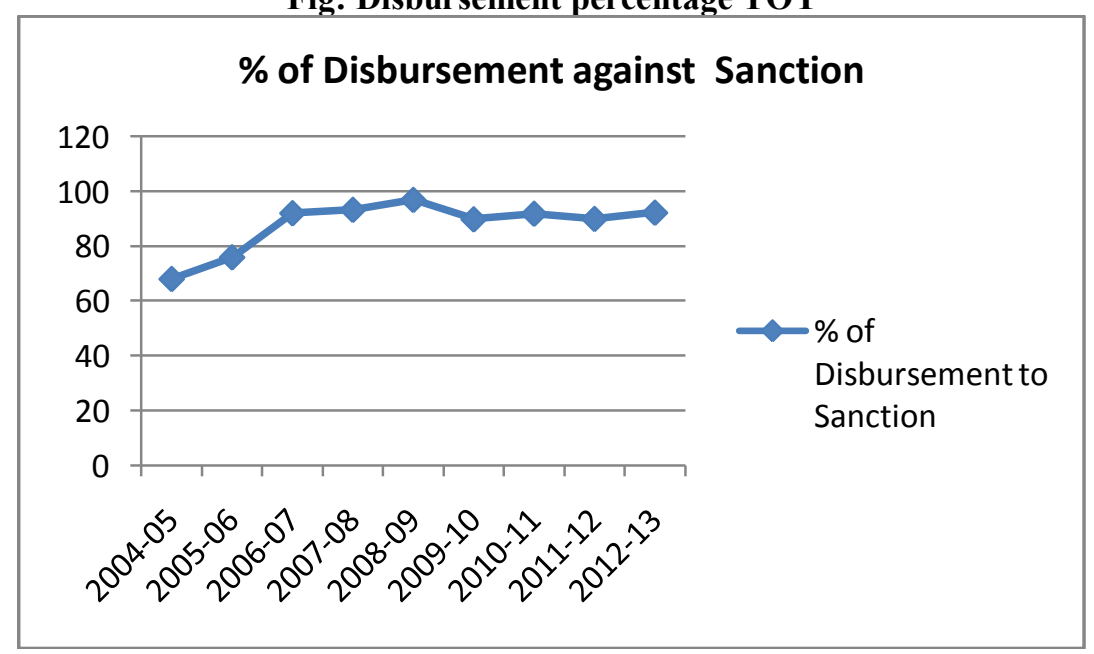


Note: The Small Industries Development Bank of India (Sidbi) has posted a net profit of Rs 837 crore for the financial year 2012-13, which is $47.7 \%$ higher than Rs 567 crore in the previous financial year.

Out of this, Rs 187 crore was a one-time refund from Income Tax Department, including interest of Rs 45 crore. Excluding this, the growth in net profit is $14.6 \%$, said a press release issued by Sidbi. The total gross income of the bank grew to Rs 5,401 crore, from Rs 4,607 crore. The bank's board approved a dividend of $25 \%$ for the just ended fiscal.

SIDBI also got 2 international awards during the year 2012-13 from Association of Development Financing Institutions in Asia and the Pacific (ADFIAP) in the areas of (a) Energy Efficiency Improvements in Furnaces used in SME Steel Industry Clusters in India; and, (b) WB-GEF Project: Financing Energy Efficiency in MSMEs under the category of Environmental Development in 5 clusters.

\section{Conclusion:}

MSMEs play a significant role as the growth engines of the Indian Economy. In fact, they have been playing a critical role in the socio-economic development of the country. Their main objectives have been mass employment generation, low investment, Import substitution, export earnings, labor intensive mode of production, capacity to develop indigenous technology and high contribution to domestic production. MSME sector is heterogeneous, highly dispersed and mostly unorganized.

The biggest problem of MSMEs is the unduly delayed payments by large industry players. The other problems are lack of infrastructure inputs and banking support. Now it is obvious that Indian MSMEs are striving to be on par with their counterparts in technology development. While in countries like China, North Korea and Taiwan, apart from hand-holding by the Government and banks, large corporates support them through prompt payments. A strong business model was nurtured in these countries instead of a subsidy mindset adopted in India.

The MSME sector is yet to realize fully the benefits of liberalization and deregulation. There is a need to uplift the MSMEs not only technologically, but otherwise too. MSMEs still face the problem of obtaining the timely and affordable credit. The sector is still neglected by the Banks and Financial Institutions in the Private Sector, which are neglecting the mandatory $40 \%$ priority sector lending. The proposed SME Stock Exchanges should take initiative to raise capital from the public

SIDBI would continue to identify the gaps in the MSME clusters and address those gaps through innovative solutions viz. loan syndication, capacity building of MSME sector, common facility centre, cluster diagnostic studies, credit facilitation centre, credit counselling and advisory services including market information, supporting skill development institutes, supporting incubation and innovation centres, setting up of website to address information asymmetry for the prospective and new entrepreneurs, coming out with various studies / reports / web-based solutions to address information gap, etc. These developmental initiatives would not only address the emerging needs of the sector, but also will create employment opportunities in this productive sector of the economy.

\section{References}

[1] The journal of Indian Institute of Banking and Finance,

[2] SIDBI Annual Reports,

[3] www.sidbi.com,

[4] www.iisd.org

[5] www.msme.gov.in

[6] Annual reports of MSME,S 